\title{
Plant phenolic extracts as an effective strategy to control Staphylococcus aureus, the dairy industry pathogen
}

\author{
Fernanda Gomes ${ }^{\mathrm{a}, *}$, Natália Martins ${ }^{\mathrm{b}, \mathrm{c}}$, Lillian Barros ${ }^{\mathrm{b}}$, Maria Elisa Rodrigues ${ }^{\mathrm{a}}$, \\ M. Beatriz P.P. Oliveira ${ }^{c}$, Mariana Henriques ${ }^{\mathrm{a}}$, Isabel C.F.R. Ferreira ${ }^{\mathrm{b}}$ \\ ${ }^{a}$ CEB, Centre of Biological Engineering, LIBRO-Laboratório de Investigação em Biofilmes Rosário Oliveira, University of Minho, $4710-057$ Braga, Portugal

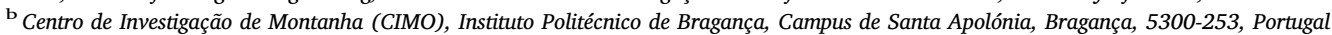 \\ ${ }^{\mathrm{c}}$ REQUIMTE/LAQV, Faculdade de Farmácia, Universidade do Porto, Rua Jorge Viterbo Ferreira, $n^{\circ} 228$, Porto, 4050-313, Portugal
}

\section{A R T I C L E I N F O}

\section{Keywords:}

Antibacterial activity

Dairy food industry

Phenolic extracts

Staphylococcus aureus

\begin{abstract}
A B S T R A C T
Staphylococcus aureus is one of the most common contagious mastitis pathogens. Bovine mastitis is considered an important reservoir for dairy industry contamination, and therefore to ensure $S$. aureus control has gained a pivotal importance. Natural matrices present multiple biological effects, being its antimicrobial potential increasingly reported. Thus, the present study aims to assess the antibacterial activity of several methanol:water extracts, obtained from plants, against Staphylococcus aureus. Moreover, the most effective extract was characterized in terms of phenolic compounds, by using high performance liquid chromatography coupled to diode array and mass spectrometer detectors. Among the tested extracts, Eucalyptus globulus was the most effective against all tested $S$. aureus strains, followed by Juglans regia and Foeniculum vulgare. Inhibition halos of the plant extracts varied between $8.0-16.0 \mathrm{~mm}$, excepting for $F$. vulgare in which two evident halos were observed: one with growth inhibition $(5.0-7.0 \mathrm{~mm})$ and a second one with visible cell density reduction $(13.0-14.0 \mathrm{~mm})$. Susceptibility assays evidenced that E. globulus extract exerted the highest antibacterial activity $(\mathrm{MICs}=0.195-0.39 \mathrm{mg} / \mathrm{mL}$ ), being effective against all the tested strains. Among the phenolic compounds identified in this extract, gallotannins, ellagic acid glycoside, and quercetin derivatives, were the most abundant; and therefore, may exert a positive and contributive effect to the observed antibacterial effect. Overall, the use of plant extracts to control bovine mastitis caused by $S$. aureus is a promising solution that could contribute to the reduction of the occurrence of dairy food industry contaminations, providing considerable benefits to agroindustries on the formulation of high-quality and safety dairy products.
\end{abstract}

\section{Introduction}

Bovine mastitis is the most expensive disease for the worldwide dairy industries. The management of this pathology is mainly based on the extensive use of antibiotics/disinfectants (Pieterse and Todorov, 2010), which has triggered the development of complicated scenarios of antimicrobial resistance (Motlagh et al., 2013). Beyond the poor efficacy of the antibiotic treatment, bovine mastitis has become increasingly difficult both to control and mainly to eradicate in many herds (Carter and Kerr, 2003; Sutra and Poutrel, 1994).

The increasing rates of antibiotic resistance hamper an urgent and effective bovine mastitis management, at the same time that motivate the search for effective antimicrobials (Rossi et al., 2011). Among the etiological agents for this complicated infection, Staphylococcus aureus is considered the most prevalent; moreover, and due to its zoonotic potential, a pivotal attention has driven an increasing solicitude by dairy industries (Kummel et al., 2016). Recently, Kummel et al. (2016) showed that $S$. aureus from bovine mastitis can enter in the dairy chain production via contaminated milk, which is in accordance with the previous study carried out by Sabour et al. (2004), who described the presence of antibiotic-resistant Staphylococcus species in milk processing lines, associated with chronic mastitis. Based on these findings, it becomes of the utmost importance to discover more effective, safer and selective control strategies, not only to reduce the number of microorganisms present in milking installations, but also to reduce the likelihood of bovine mastitis and milk contamination occurrence.

Natural matrices have been increasingly reported as effective alternatives to the current antimicrobial agents. In fact, the use of botanical preparation dates back from the beginning of human civilization, being effectively used in a wide variety of health conditions (Saranraj and Sivasakthi, 2014). As a rich source of bioactive molecules, among them phenolic compounds, natural matrices are commonly defined as

\footnotetext{
* Corresponding author.

E-mail address: fernandaisabel@deb.uminho.pt (F. Gomes).
} 
"prototypes of new antimicrobial agents" (Meléndez and Capriles, 2006). Several studies have supported the effective use of botanical preparations against bovine mastitis pathogens, being aqueous and alcoholic extracts the most commonly used (Diaz et al., 2010; Doss et al., 2012; Mubarack et al., 2011; Rossi et al., 2011). However, to the authors' best knowledge no previous studies have assessed the antibacterial activity of methanol: water plant extracts against $S$. aureus isolated from bovine mastitis. In this sense, the present work aims to evaluate the antibacterial activity of fourteen methanol: water extracts against different $S$. aureus strains isolated from bovine mastitis, towards providing new insights for an effective control of dairy industry contaminations; as also to perform the characterization in terms of phenolic compounds of the most effective plant extract.

\section{Materials and methods}

\subsection{Plant samples}

A total of fourteen plant species were used: four of them were wild samples, harvested in Trás-os-Montes - Bragança, North-Eastern Portugal, namely petals of Rosa canina L. (rose hips/dog rose), leaves of Juglans regia L. (walnut), flower buds and fully opened flowers of Rubus ulmifolius Schott (elm-leaved blackberry), and leaves and roots of Fragaria vesca L. (wild strawberry). The other ones were commercial samples, namely fruits of Pimpinella anisum L. (anise) and Coriandrum sativum L. (coriander); leaves of Melissa officinalis L. (lemonbalm), Eucalyptus globulus Labill. (blue gum) and Tabebuia impetiginosa (Mart. ex DC) Standley (pau d'arco); aerial parts of Foeniculum vulgare Miller (fennel), Matricaria recutita L. (chamomile) and Echinacea purpurea (L.) Moench (purple coneflower), and lastly flowering parts of Pterospartum tridentatum (L.) Willk (carqueja). Plant scientific nomenclature is according The Plant List (2013), version 1.1 (2013).

\subsection{Standards and reagents}

Acetonitrile (99.9\%, HPLC grade) and methanol (99\%, PA) were from Fisher Scientific (Lisbon, Portugal). Phenolic standards were from Extrasynthèse (Genay, France). Formic acid was from Sigma-Aldrich (St. Louis, MO, USA). Tryptic Soy Broth (TSB) and Agar were purchased from Liofilchem (Roseto degli Abruzzi, Italy) and Merck (Darmstadt, Germany), respectively. Water was treated in a Milli-Q water purification system (TGI Pure Water Systems, Carrollton, USA).

\subsection{Preparation of the extracts}

Methanol: water extracts were obtained by extracting each plant sample ( $1 \mathrm{~g})$ with $30 \mathrm{~mL}$ of methanol: water $(80: 20$, v/v) mixture at $25^{\circ} \mathrm{C}$ and $150 \mathrm{rpm}$ for $1 \mathrm{~h}$, and filtering through Whatman No. 4 paper. Final residue was then extracted with an additional $30 \mathrm{~mL}$ portion of the methanol: water mixture. Each one of the combined extracts was evaporated at $35^{\circ} \mathrm{C}$ under reduced pressure (rotary evaporator Büchi R210, Flawil, Switzerland) and then lyophilized (FreeZone 4.5, Labconco, Kansas City, MO, USA). The lyophilized methanol: water extracts were re-dissolved in water to obtain stock solutions at $50 \mathrm{mg}$ / $\mathrm{mL}$, from which several dilutions were prepared.

\subsection{Evaluation of the antibacterial activity}

\subsubsection{Disc diffusion assay}

Seven $S$. aureus strains were used in this study (Table 1), one from the American Type Culture Collection (ATCC 25923), and six clinical isolates from cows with mastitis (North region of Portugal). The clinical isolates were provided by Segalab (Laboratório de Sanidade Animal e Segurança Alimentar, S. A.).

All strains were inoculated into $15 \mathrm{~mL}$ of TSB from Tryptic Soy Agar (TSA) plates not older than 2 days, and grown for $24 \mathrm{~h}$ at $37^{\circ} \mathrm{C}$ in an orbital shaker at $120 \mathrm{rpm}$. Cells were harvested by centrifugation (for $5 \mathrm{~min}$ at $9500 \mathrm{~g}$ at $4^{\circ} \mathrm{C}$ ), resuspended in TSB, adjusted to an optical density $(640 \mathrm{~nm})$ equivalent to $1 \times 10^{6}$ cells $/ \mathrm{mL}$ and, then used in the subsequent assays. An aliquot of each strain $(300 \mu \mathrm{L})$ was spread in TSA plates. An aliquot $(25 \mu \mathrm{L})$ of each plant extract, with a known concentration $(50 \mathrm{mg} / \mathrm{mL})$, was placed on a sterile blank disc. Sterile water was used as negative control. Then, plates were incubated at $37^{\circ} \mathrm{C}$, during $24-48 \mathrm{~h}$, and the determination of inhibitory effects was performed measuring the corresponding zones of inhibition (inhibition halo diameter).

\subsubsection{Determination of minimal inhibitory concentrations (MICs)}

Minimal inhibitory concentrations (MICs) were determined by microbroth dilution technique, to the plant extracts in which most pronounced effects were observed, considering the results obtained in the disc diffusion assay. MIC values were determined to the selected plant extracts by serial two-fold dilutions method, at concentrations ranging from $0.049 \mathrm{mg} / \mathrm{mL}$ to $6.25 \mathrm{mg} / \mathrm{mL}$, adjusting final cellular concentration to $5 \times 10^{5}$ cells $/ \mathrm{mL}$. The 96 -wells plates (Orange Scientific, Brainel'Alleud, Belgium) were incubated at $37^{\circ} \mathrm{C}$ for $24-48 \mathrm{~h}$. Sample and bacteria-free controls were also included. After visualization of the resultant plate, MIC values corresponded to the concentration used in which no visible growth was observed, or a bacteriostatic effect was observed by comparison with positive controls (cells grown without extracts). Then, the number of viable cells was assessed by determination of the number of colony forming units (CFUs), after $24 \mathrm{~h}$ of incubation at $37{ }^{\circ} \mathrm{C}$. The number of colonies formed was counted and the results presented as the total of CFUs (Log CFUs). Experiments were carried out in triplicate, and repeated in three independent occasions.

\subsection{Phenolic compounds analysis}

The most effective extract was characterized regarding its phenolic composition. Therefore, it was re-dissolved at a concentration of $5 \mathrm{mg} /$ $\mathrm{mL}$ with $80 \%$ methanol, filtered through a $0.22-\mu \mathrm{m}$ disposable LC filter disc before the chromatographic analysis. The phenolic profile was determined by HPLC-DAD-ESI/MSn (Dionex Ultimate 3000 UPLC, Thermo Scientific, San Jose, CA, USA), following a procedure previously described by Bessada et al. (2016). Detection was achieved with DAD (280, 330 and $370 \mathrm{~nm}$ as preferred wavelengths) and in a mass spectrometer (MS). The MS detection was performed in negative mode, using a Linear Ion Trap LTQ XL mass spectrometer (ThermoFinnigan, San Jose, CA, USA) equipped with an ESI source. The identification of the phenolic compounds was performed using standard compounds, when available, by comparing their retention times, UV-vis and mass spectra; as also, comparing the obtained information with available data reported in literature giving a tentative identification. For quantitative analysis, a calibration curve for each available phenolic standard was constructed based on the UV signal. For the identified phenolic compounds for which a commercial standard was not available, the quantification was performed through the calibration curve of the most similar available standard, such as for compounds. The results were expressed as mg per $\mathrm{g}$ of extract.

\subsection{Statistical analysis}

Data were analyzed using one-way analysis of variance (ANOVA) and means were compared using Tukey's honestly significant difference (HSD) multiple comparisons test. All statistical tests were performed using Prism software package (GraphPad Software version 6.0 for Macintosh). Results were considered statistically significant when $P<0.05$. 
Table 1

Antibacterial activity of the hydromethanolic extracts from different plant origin, against Staphylococcus aureus isolates.

\begin{tabular}{|c|c|c|c|c|c|c|c|}
\hline \multirow[t]{2}{*}{ Plant extracts } & \multicolumn{7}{|l|}{ Inhibition zones (mm) } \\
\hline & S. aureus ATCC 25923 & S. aureus 1 & S. aureus 2 & S. aureus 3 & S. aureus 4 & S. aureus 5 & S. aureus 6 \\
\hline Coriandrum sativum $\mathrm{L}$. & - & - & - & - & - & - & - \\
\hline Echinacea purpurea (L.) Moench & - & - & - & - & - & - & - \\
\hline Eucalyptus globulus Labill. & 10 & 12 & 10 & 8 & 14 & 11 & 15 \\
\hline Foeniculum vulgare Miller & $5 / 13^{a}$ & $6 / 14^{a}$ & $5 / 14^{a}$ & $6 / 14^{\mathrm{a}}$ & $7 / 13^{a}$ & $5 / 14^{a}$ & $6 / 14^{a}$ \\
\hline Fragaria vesca L. leaves & 6 & 6 & 7 & 6 & 9 & 6 & 7 \\
\hline Fragaria vesca L. roots & 6 & 6 & 6 & 6 & 9 & 5 & 8 \\
\hline Juglans regia L. & 14 & 15 & 14 & 13 & 12 & 16 & 16 \\
\hline Matricaria recutita $\mathrm{L}$. & 5 & 4 & 4 & 5 & 9 & 6 & 6 \\
\hline Melissa officinalis L. & 8 & 9 & 8 & 8 & 9 & 10 & 8 \\
\hline Pimpinella anisum $\mathrm{L}$. & - & - & - & - & - & - & - \\
\hline Pterospartum tridentatum (L.) Willk. & 5 & 5 & 6 & 3 & 7 & 5 & 5 \\
\hline Rosa canina $\mathrm{L}$. & - & - & - & - & - & - & - \\
\hline Rubus ulmifolius Schott & 8 & 8 & 9 & 8 & 9 & 10 & 10 \\
\hline Tabebuia impetiginosa (Mart. ex DC) Standley & - & - & - & - & - & - & - \\
\hline
\end{tabular}

(-) Absence of antibacterial activity.

${ }^{a}$ Inhibition zone/cell density reduction.

\section{Results}

\subsection{Antibacterial activity}

Table 1 shows the obtained results for the screening of antibacterial activity, using disc diffusion assay. Among the tested plant extracts, $E$. globulus and $J$. regia revealed to be the most effective against most of tested strains, and the inhibition zones varied, respectively, between 8 and 15 and $12-16 \mathrm{~nm}$. For $F$. vulgare extract a significant effect was also observed, being evident two different halos: one of complete growth inhibition - weak halo (5-7 mm), and another with visible cell density reduction - strong halo $(13-14 \mathrm{~mm})$. These results suggest that $F$. vulgare extract mainly exerted bacteriostatic effects. On the other hand, for $M$. officinalis and $R$. ulmifolius extracts only moderate halos were observed (ranging from 8 to $10 \mathrm{~mm}$ ), while weak inhibition zones were observed in $M$. recutita, $F$. vesca, and $P$. tridentatum extracts, being stated tenuous variations according the tested $S$. aureus strains. Finally, at the tested concentration $(50 \mathrm{mg} / \mathrm{mL})$, no positive results were observed in C. sativum, E. purpurea, P. anisum, $R$. canina and T. impetiginosa extracts.

Subsequently, aiming to deepen knowledge and to confirm the results obtained, for plant extracts which evidenced the most pronounced antibacterial potential, namely E. globulus, $J$. regia and $F$. vulgare extracts, antimicrobial susceptibility tests (MIC and CFUs determination) were performed, and the results obtained presented in Table 2 and Fig. 1. Regarding the results obtained in the susceptibility tests, it was evident the bactericidal effect of $J$. regia and E. globulus extracts, causing a full growth inhibition of $S$. aureus strains, while for $F$. vulgare extract only bacteriostatic effects were reached against all tested strains. However, among the three tested extracts, E. globulus clearly evidenced to be the most effective, presenting the lowest MIC value $(0.19$ $0.39 \mathrm{mg} / \mathrm{mL}$ ), followed by $J$. regia $(0.78-1.56 \mathrm{mg} / \mathrm{mL})$ and, then $F$. vulgare extracts ( 3.125 to $>6.25 \mathrm{mg} / \mathrm{mL}$ ). After $24 \mathrm{~h}$-incubation, a half MIC value of $E$. globulus extract could decrease by $65-85 \%(0.5-0.8 \log$ reduction) the viability of all tested strains $(\mathrm{P}<0.05)$, while at concentrations higher than MIC were sufficient to full inhibit $S$. aureus growth (Fig. 1).

\subsection{Phenolic compounds analysis}

Rosa canina (Guimarães et al., 2013b), Juglans regia (Santos et al., 2013), Rubus ulmifolius (Martins et al., 2014a), Fragaria vesca (Dias et al., 2015), Pimpinella anisum (Martins et al., 2016), Coriandrum sativum (Martins et al., 2016), Melissa officinalis (Barros et al., 2013), Foeniculum vulgare (Caleja et al., 2015), Matricaria recutita (Guimarães et al., 2013a), Echinacea purpurea (Pires et al., 2016) and Pterospartum tridentatum (Roriz et al., 2014) extracts were previously chemically characterized by our research group. In the present study, we performed the characterization of the most active extract. Thus, the phenolic profile of E. globulus, obtained after methanol/water extraction, and recorded at $280 \mathrm{~nm}$ is shown in Fig. 2; peak characteristics and tentative identities are presented in Table 3. Nineteen phenolic compounds were detected, sixteen of which were flavonoids (mainly quercetin derivatives) and three phenolic acids (mainly gallic and ellagic acids derivatives). Compounds 3 (5-O-caffeoylquinic acid), 11 (quercetin-3-O-glucuronide) and 12 (quercetin-3-O-glucoside) were positively identified according to their retention times, mass spectra and UV-vis characteristics in comparison with commercial standards. Compounds 1 and $2\left([\mathrm{M}-\mathrm{H}]^{-}\right.$at $m / z$ 483) were identified as digalloylglucoside based on its fragmentation pattern, showing two product ions at $m / z 313$ (loss of a galloyl moiety) and at $m / z 169$ (deprotonated gallic acid), as already reported by Santos et al. (2011). Compounds 4, 6 and $7\left([\mathrm{M}-\mathrm{H}]^{-}\right.$at $\left.m / z 635\right)$ were identified as trigalloyl-glucoside, corresponding to the loss of a galloyl residue as reported by Boulekbache-Makhlouf et al. (2013) in E. globulus leaves. In the same way, compounds 9 and $10\left([\mathrm{M}-\mathrm{H}]^{-}\right.$at $m / z$ 787) were assigned as tetragalloyl-glucose and compound $14\left([\mathrm{M}-\mathrm{H}]^{-}\right.$at $m / z$ 939) as pentagalloyl-glucoside (Boulekbache-Makhlouf et al., 2013).

Compounds 8 and 18 presented a UV spectra and a fragmentation pattern corresponding to ellagic acid derivatives. Compound $8\left([\mathrm{M}-\mathrm{H}]^{-}\right.$ at $m / z 463$ ) presented a fragmentation pattern yielding a product ion at

Table 2

Antibacterial activity of the tested hydromethanolic plant extracts, against $S$. aureus isolates, determined by CLSI broth microdilution method.

\begin{tabular}{|c|c|c|c|c|c|c|c|}
\hline \multicolumn{8}{|l|}{ MIC (mg/mL) } \\
\hline Plant extracts & S. aureus ATCC 25923 & S. aureus 1 & S. aureus 2 & S. aureus 3 & S. aureus 4 & S. aureus 5 & S. aureus 6 \\
\hline Juglans regia L. & 0.78 & 1.56 & 1.56 & 1.56 & 1.56 & 0.78 & 1.56 \\
\hline Eucalyptus globulus Labill. & 0.19 & 0.19 & 0.19 & 0.39 & 0.19 & 0.19 & 0.39 \\
\hline Foeniculum vulgare Miller & $>6.25$ & 6.25 & 6.25 & $>6.25$ & 6.25 & 3.125 & $>6.25$ \\
\hline
\end{tabular}




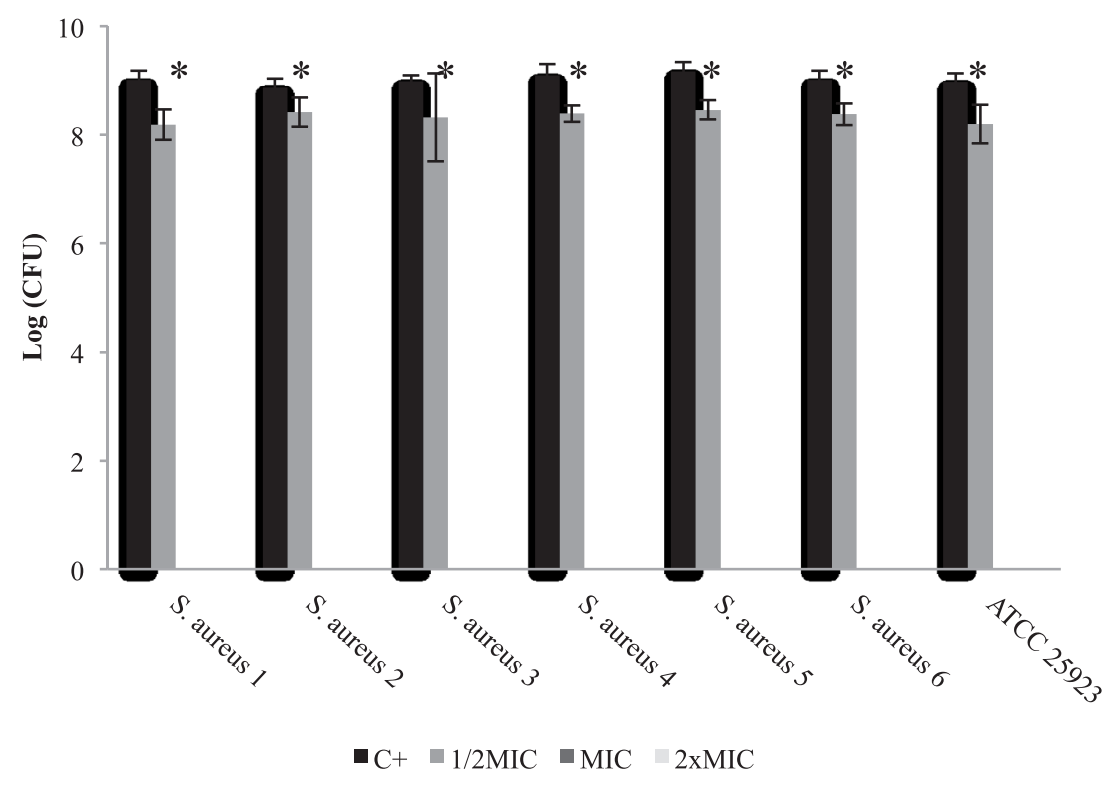

Fig. 1. Colony forming units (CFUs) of different Staphylococcus aureus strains, cultured within different concentrations of the hydromethanolic extract of Eucalyptus globulus Labill. The means \pm standard deviations for three independent assays are illustrated. $P<0.05$ (one-way ANOVA, Tukey's multiple comparisons test). $m / z 301(-162 \mathrm{u}$, loss of a glucoside moiety), being assigned to an ellagic acid glucoside. Compound $18\left([\mathrm{M}-\mathrm{H}]^{-}\right.$at $\left.m / z 447\right)$ fragmented at $m / z 315$ ( $-132 \mathrm{u}$, loss of pentosyl) and at $m / z 301$, corresponds to methylellagic acid pentoside; this compound has been previously reported in E. globulus leaves by Boulekbache-Makhlouf et al. (2013) and E. globulus bark by Santos et al. (2011). Compound $13\left([\mathrm{M}-\mathrm{H}]^{-}\right.$at $\mathrm{m} / \mathrm{z}$ 497) yielded fragment ions at $m / z 169$ and 313, with the loss of $184 \mathrm{u}$ characteristic of oleuropeic acid (Hasegawa et al., 2008), being coherent with the structure of eucaglobulin or globulusin B, which have already identified in leaves and fruits of E. globulus (BoulekbacheMakhlouf et al., 2013; Hasegawa et al., 2008).

The remaining compounds were identified as flavonoid derivatives. Compound $5\left([\mathrm{M}-\mathrm{H}]^{-}\right.$at $\left.m / z 493\right)$ was assigned to myricetin- $O$-glucuronide, being already identified in different extracts obtained from Eucalyptus species (Santos et al., 2012). Compounds 15 ([M-H] $]^{-}$at $m / z$ 433) and $16\left([\mathrm{M}-\mathrm{H}]^{-}\right.$at $m / z$ 447) with an unique $\mathrm{MS}^{2}$ fragment ion at $\mathrm{m} / \mathrm{z} 301$ (loss of a pentosyl moiety $-132 \mathrm{u}$ and rhamnosyl moiety $146 \mathrm{u}$, respectively), were assigned to quercetin derivatives, namely quercetin-O-pentoside and quercetin-O-rhamnoside. Compound 17 ([M-H] ${ }^{-}$at $m / z$ 461) was assigned to isorhamnetin-O-rhamnoside taking into account the fragmentation pattern described by Santos et al. (2011) for Eucalyptus species. Finally, no definite identification could be provided for compound $19\left([\mathrm{M}-\mathrm{H}]^{-}\right.$at $\left.m / z 547\right)$, thus being assigned as a quercetin derivative.

Overall, among the nineteen phenolic compounds identified, digalloyl-glucoside, 5-O-caffeoylquinic acid and ellagic acid glucoside, were the most abundant molecules present in Eucalyptus globulus methanol: water extract.

\section{Discussion}

To overcome the problem of antibiotics/disinfectants resistance, effective and safer alternatives to the current antimicrobial drugs need to be urgently assessed, towards bovine mastitis occurrence prevention, while major triggering factor for contamination in dairy food industries. Several studies have reported the use of plant extracts as effective antimicrobial agents, using different extraction solvents, but the assessment of methanol: water extracts efficiency still continues being scarce. For example, Martins et al. conducted an experiment using Origanum vulgare L. (Martins et al., 2014b) and Thymus vulgaris L. (Martins et al., 2015a) aqueous and methanol: water extracts against a wide variety of bacteria, including $S$. aureus. However, up to the tested concentration ( $20 \mathrm{mg} / \mathrm{mL}$ ), no positive results were achieved by the authors. Further, in the present study the selected plant species were already reported by Martins et al. (2015b) as having a promisor antifungal activity against Candida species. In that experiment, the authors emphasized the doubtless importance of extraction solvents used; in fact, the content in bioactive molecules, such as phenolic compounds is markedly affected by the type of extraction solvent used, since it affects phytochemicals solubility and consequent bioactivity (Martins et al., 2015a, 2015b). In this sense, based on the previous results obtained by the authors, in the present study fourteen plant extracts were screened for its antibacterial activity against six different $S$. aureus strains isolated from bovine mastitis and one reference strain.

Among the studied plant extracts, E. globulus revealed to be the most effective against all strains tested, presenting the higher inhibition halo and lower MIC values. In fact, whenever it is intended to select an antimicrobial drug, MIC value must be taken into consideration, since a lower MIC value indicates that a lower concentration of drug is

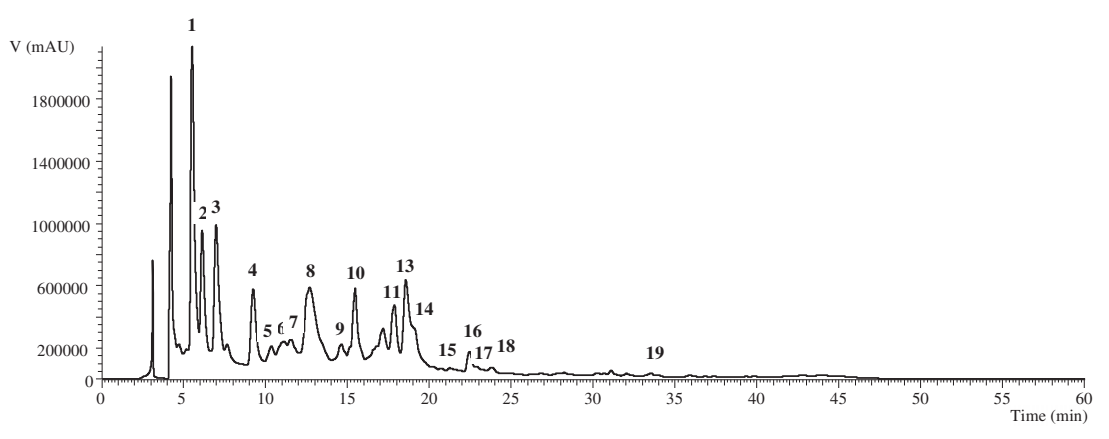

Fig. 2. Phenolic profile of Eucalyptus globulus Labill. methanol/water (80:20, v/v) extract at $280 \mathrm{~nm}$. 
Table 3

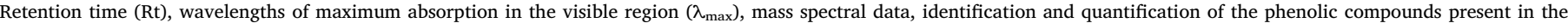
methanol/water extract of Eucalyptus globulus Labill.

\begin{tabular}{|c|c|c|c|c|c|c|}
\hline Peak & Rt (min) & $\begin{array}{l}\lambda_{\max } \\
(\mathrm{nm})\end{array}$ & $\begin{array}{l}\text { Molecular ion [M- } \\
\mathrm{H}]^{-}(m / z)\end{array}$ & $\operatorname{MS}^{2}(m / z)$ & $\begin{array}{l}\text { Tentative } \\
\text { identification }\end{array}$ & $\begin{array}{l}\text { Quantification (mg/g } \\
\text { extract) }\end{array}$ \\
\hline 1 & 5.51 & 276 & 483 & $331(24), 313(21), 271(100), 211(7), 169(5)$ & Digalloyl-glucoside & $30.5 \pm 1.2$ \\
\hline 2 & 6.15 & 272 & 483 & $331(30), 313(19), 271(100), 211(10), 169(7)$ & Digalloyl-glucoside & $13.7 \pm 0.1$ \\
\hline 3 & 6.98 & 328 & 353 & $191(100), 179(22), 161(5), 135(5)$ & $\begin{array}{l}\text { 5-O-Caffeoylquinic } \\
\text { acid }\end{array}$ & $22.3 \pm 0.3$ \\
\hline 4 & 9.25 & 277 & 635 & 483(17),465(100),313(12),211(5),169(3) & Trigalloyl-glucoside & $12 \pm 1$ \\
\hline 5 & 10.36 & 340 & 493 & $317(100)$ & $\begin{array}{l}\text { Myricetin- } O \text { - } \\
\text { glucuronide }\end{array}$ & $1.90 \pm 0.03$ \\
\hline 6 & 10.84 & 277 & 635 & $483(100), 465(10), 331(5), 313(7), 271(5), 211(5), 169(3)$ & Trigalloyl-glucoside & $6.1 \pm 0.2$ \\
\hline 7 & 11.54 & 278 & 635 & $483(100), 465(44), 313(11), 211(6), 169(3)$ & Trigalloyl-glucoside & $5.8 \pm 0.2$ \\
\hline 8 & 12.71 & $\begin{array}{l}253 / \\
\operatorname{sh} 360\end{array}$ & 463 & $301(100)$ & Ellagic acid glucoside & $21.6 \pm 0.3$ \\
\hline 9 & 14.64 & 276 & 787 & $635(28), 617(31), 483(84), 465(100), 447(6), 423(73), 313(10), 271(9), 169(5)$ & Tetragalloyl-glucose & $5.8 \pm 0.3$ \\
\hline 10 & 15.47 & 277 & 787 & 635(37),617(22),483(55),465(100),447(62),423(15),313(7),271(5),169(3) & Tetragalloyl-glucose & $11.6 \pm 0.5$ \\
\hline 11 & 17.89 & 355 & 477 & $301(100)$ & $\begin{array}{l}\text { Quercetin-3-O- } \\
\text { glucuronide }\end{array}$ & $7.7 \pm 0.2$ \\
\hline 12 & 18.45 & 350 & 463 & $301(100)$ & $\begin{array}{l}\text { Quercetin-3-O- } \\
\text { glucoside }\end{array}$ & $3.7 \pm 0.1$ \\
\hline 13 & 18.81 & 283 & 497 & $313(49), 169(100)$ & $\begin{array}{l}\text { Eucaglobulin/ } \\
\text { Globulusin B }\end{array}$ & $13.9 \pm 0.4$ \\
\hline 14 & 19.12 & 277 & 939 & $787(100), 635(22), 617(28), 465(33)$ & Pentagalloyl-glucoside & $6.5 \pm 0.1$ \\
\hline 15 & 21.26 & 354 & 433 & $301(100)$ & Quercetin-O-pentoside & $1.34 \pm 0.01$ \\
\hline 16 & 22.44 & 354 & 447 & $301(100)$ & $\begin{array}{l}\text { Quercetin-O- } \\
\text { rhamnoside }\end{array}$ & $3.2 \pm 0.1$ \\
\hline 17 & 23.29 & 358 & 461 & $315(100)$ & $\begin{array}{l}\text { Isorhametin-O- } \\
\text { rhamnoside }\end{array}$ & $1.16 \pm 0.02$ \\
\hline 18 & 23.82 & $\begin{array}{l}250 / \\
\operatorname{sh} 364\end{array}$ & 447 & $315(100), 301(28)$ & $\begin{array}{l}\text { Methylellagic acid } \\
\text { pentoside }\end{array}$ & $3.2 \pm 0.1$ \\
\hline \multirow[t]{2}{*}{19} & 33.52 & 355 & 547 & 463(47),301(100) & Quercetin derivative & $1.47 \pm 0.02$ \\
\hline & & & & & $\begin{array}{l}\text { Total phenolic } \\
\text { compounds }\end{array}$ & $173 \pm 4$ \\
\hline
\end{tabular}

necessary to inhibit microbial growth, being also the infectious agent less resistant to the tested drug (Dafale et al., 2016). As mentioned before, the MIC value of E. globulus could promote $100 \%$ of growth inhibition. These results were similar to those obtained by Rossi et al. (2011) with hexane extracts of $H$. nymphoides and $S$. auriculata. Even though not tested directly against bovine mastitis-related strains, the results obtained by Martins et al. (2015b) using these plant extracts against different Candida species, highlight the broad-spectrum activity of methanol: water extracts, which is in accordance with the results obtained in the present study. This achievement revealed to be a crucial advantage, since in bovine mastitis several etiological agents (bacterial and mycotic mastitis) are involved.

Several plant-derived phenolic extracts were previously reported as having prominent antimicrobial effects. Senna macranthera (Coll.) H. S. Irwin \& Barneby var. macranthera (ethanol extract), Artemisia absinthium L. (dichloromethane extract), Cymbopogon nardus (L.) Rendle (80\% ethanol/water extract) and Baccharis dracunculifolia D.C. (ethanol extract) extracts were markedly highlighted as effective antimicrobials in the management of this pathology (MIC values varied from $0.5-1.0 \mathrm{mg} / \mathrm{mL}$ ) (Diaz et al., 2010). On the other hand, Rossi et al. (2011) also assessed the antimicrobial potential of several plant extracts from aquatic origin, namely Salvinia auriculata Aubl. and Hydrocleys nymphoides (Willd.) Buchenau, against bovine pathogens. The authors observed that hexane extracts were the most active preparations, ranging MIC values from 0.2 to $1.0 \mathrm{mg} / \mathrm{mL}$ (Rossi et al., 2011). Despite the promissory results obtained by the authors, the use of this organic solvent present some drawbacks, such as environmental and adverse health effects (Tanzi et al., 2012). Further, Mubarack et al. (2011) and Doss et al. (2012), evaluating the antimicrobial effect of different plant extract preparations (aqueous and alcoholic extracts) against several mastitis pathogens, also found very interesting results: inhibition zones varied from 8.0 to $25.0 \mathrm{~mm}$, and the corresponding MIC values from 0.125 to $2.0 \mathrm{mg} / \mathrm{mL}$. All the previously mentioned plant extracts were already tested against $S$. aureus, being the results achieved similar those of the present work. Moreover, despite the difference in the extraction solvents used, the authors highlighted that the intramammary use of the tested plant extracts (mainly aqueous extract - infusion) might constitute an upcoming antimicrobial agent, used alone or even combined with antibiotics, aiming to ensure an effective treatment of bovine mastitis.

In fact, natural matrices have been increasingly recognized as a rich source of bioactive molecules, among them phenolic compounds with pronounced antioxidant and antimicrobial effects, being even reported their useful incorporation in new antimicrobial products development (Mordmuang et al., 2015). Since E. globulus was the most effective plant extract tested, its phenolic characterization was performed aiming to determine which phenolic compounds were responsible for the observed antibacterial activity. Gallotannins, ellagic acid glycosides and quercetin derivatives were the most abundant phenolic compounds present in the E. globulus extract, and might be involved in the positive effects observed. These phytochemicals were already recognized as antimicrobial compounds namely against $S$. aureus and in some cases against biofilms cells, being possibly responsible for the bioactivity presented by E. globulus leaves hydroalcoholic extracts (Al-Zahrani, 2012; Amin et al., 2015; Fontaine et al., 2017). Thus, the results obtained drew attention for the possible use of E. globulus and J. regia extracts in combination with other drugs, both to control bovine mastitis and even dairy food industry contaminations. In fact, through using a proper combination strategy, it will be possible to achieve a greater efficacy (synergy) using lower doses of chemical drugs, also reducing the development of microbial drug resistance and preventing side effects occurrence. On the other hand, these results also highlight the possible use of these natural antimicrobial agents as disinfectants for surfaces cleaning and disinfection, with the objective of ensuring a better control of pathogenic microorganisms, responsible for bovine mastitis and dairy food industry contaminations. 


\section{Acknowledgements}

This study was supported by the Portuguese Foundation for Science and Technology (FCT) (grant number SFRH/BPD/84488/2012) under the scope of the strategic funding of UID/BIO/04469/2013 unit and COMPETE 2020 (POCI-01-0145-FEDER-006684) and BioTecNorte operation (NORTE-01-0145-FEDER-000004) funded by European Regional Development Fund under the scope of Norte2020 - Programa Operacional Regional do Norte, as also Pest-OE/AGR/UI0690/2013 to CIMO. The authors are also grateful to the Interreg España-Portugal for financial support through the project 0377_Iberphenol_6_E and to Ana Maria Carvalho for the collection and identification of the wild samples, chemically characterized in previous studies.

\section{References}

Al-Zahrani, S.H., 2012. Antibacterial activities of gallic acid and gallic acid methyl ester on methicillin-resistant. J. Am. Sci. 8, 7-12.

Amin, M.U., Khurram, M., Khattak, B., Khan, J., 2015. Antibiotic additive and synergistic action of rutin: morin and quercetin against methicillin resistant Staphylococcus aureus. BMC Complement. Altern. Med. 15, 1-12.

Barros, L., Dueñas, M., Dias, M.I., Sousa, M.J., Santos-Buelga, C., Ferreira, I.C.F.R., 2013. Phenolic profiles of cultivated: in vitro cultured and commercial samples of Melissa officinalis L. infusions. Food Chem. 136, 1-8.

Bessada, S.M., Barreira, J.C.M., Barros, L., Ferreira, I.C.F.R., Oliveira, M.B.P.P., 2016. Phenolic profile and antioxidant activity of Coleostephus myconis (L.) Rchb. f.: An underexploited and highly disseminated species. Ind. Crops Prod. 89, 45-51.

Boulekbache-Makhlouf, L., Meudec, E., Mazauric, J.-P., Madani, K., Cheynier, V., 2013. Qualitative and semi-quantitative analysis of phenolics in Eucalyptus globulus leaves by high-performance liquid chromatography coupled with diode array detection and electrospray ionisation mass spectrometry. Phytochem. Anal. 24, 162-170. http://dx. doi.org/10.1002/pca.2396

Caleja, C., Barros, L., Antonio, A.L., Ciric, A., Soković, M., Oliveira, M.B.P.P., SantosBuelga, C., Ferreira, I.C.F.R., 2015. Foeniculum vulgare Mill. as natural conservation enhancer and health promoter by incorporation in cottage cheese. J. Funct. Foods 12, 428-438. http://dx.doi.org/10.1016/j.jff.2014.12.016.

Carter, E.W., Kerr, D.E., 2003. Optimization of DNA-based vaccination in cows using green fluorescent protein and protein $\mathrm{A}$ as a prelude to immunization against staphylococcal mastitis. J. Dairy Sci. 86, 1177-1186. http://dx.doi.org/10.3168/jds. S0022-0302(03)73701-1.

Dafale, N.A., Semwal, U.P., Rajput, R.K., Singh, G.N., 2016. Selection of appropriate analytical tools to determine the potency and bioactivity of antibiotics and antibiotic resistance. J. Pharm. Anal. 6, 207-213.

Dias, M.I., Barros, L., Fernandes, I.P., Ruphuy, G., Oliveira, M.B.P.P., Santos-Buelga, C., Barreiro, M.F., Ferreira, I.C.F.R., 2015. A bioactive formulation based on Fragaria vesca L. vegetative parts: chemical characterisation and application in k-carrageenan gelatin. J. Funct. Foods 16, 243-255. http://dx.doi.org/10.1016/j.jff.2015.04.044.

Diaz, M.A.N., Rossi, C.C., Mendonça, V.R., Silva, D.M., Ribon, A.O.B., Aguilar, A.P., Muñoz, G.D., 2010. Screening of medicinal plants for antibacterial activities on Staphylococcus aureus strains isolated from bovine mastitis. Rev. Bras. Farmacogn. 20, 724-728. http://dx.doi.org/10.1590/S0102-695x2010005000013.

Doss, A., Muhamed Mubarack, H., Vijayasanthi, M., Venkataswamy, R., 2012. In-vitro antibacterial activity of certain wild medicinal plants against bovine mastitis isolated contagious pathogens. Asian J. Pharm. Clin. Res. 5, 90-93.

Fontaine, B.M., Nelson, K., Lyles, J.T., Jariwala, P.B., Garcia-Rodriguez, J.M., Quave, C.L., et al., 2017. Identification of ellagic acid rhamnoside as a bioactive component of a complex botanical extract with anti-biofilm activity. Front. Microbiol. 8, 1-12.

Guimarães, R., Barros, L., Dueñas, M., Calhelha, R.C., Carvalho, A.M., Santos-Buelga, C., Queiroz, M.J.R.P., Ferreira, I.C.F.R., 2013a. Infusion and decoction of wild German chamomile: bioactivity and characterization of organic acids and phenolic compounds. Food Chem. 136, 947-954. http://dx.doi.org/10.1016/j.foodchem.2012.09. 007.

Guimarães, R., Barros, L., Dueñas, M., Carvalho, A.M., Queiroz, M.J.R.P., Santos-Buelga, C., Ferreira, I.C.F.R., 2013b. Characterisation of phenolic compounds in wild fruits from Northeastern Portugal. Food Chem. 141, 3721-3730. http://dx.doi.org/10. 1016/j.foodchem.2013.06.071.

Hasegawa, T., Takano, F., Takata, T., Niiyama, M., Ohta, T., 2008. Bioactive monoterpene glycosides conjugated with gallic acid from the leaves of Eucalyptus globulus. Phytochemistry 69, 747-753. http://dx.doi.org/10.1016/j.phytochem.2007.08.030.
Kummel, J., Stessl, B., Conano, M., Walcher, G., Bereuter, O., Fricker, M., Grunert, T., Wagner, M., Ehling-Schulz, M., 2016. Staphylococcus aureus entrance into the dairy chain: tracking S. aureus from dairy cow to cheese. Front. Microbiol. 7, 1-11.

Martins, A., Barros, L., Carvalho, A.M., Santos-Buelga, C., Fernandes, I.P., Barreiro, F., Ferreira, I.C.F.R., 2014a. Phenolic extracts of Rubus ulmifolius Schott flowers: characterization, microencapsulation and incorporation into yogurts as nutraceutical sources. Food Funct. 5, 1091. http://dx.doi.org/10.1039/c3fo60721f.

Martins, N., Barros, L., Santos-Buelga, C., Henriques, M., Silva, S., Ferreira, I.C.F.R., 2014b. Decoction, infusion and hydroalcoholic extract of Origanum vulgare L.: different performances regarding bioactivity and phenolic compounds. Food Chem. 158, 73-80. http://dx.doi.org/10.1016/j.foodchem.2014.02.099.

Martins, N., Barros, L., Santos-Buelga, C., Silva, S., Henriques, M., Ferreira, I.C.F.R., 2015a. Decoction, infusion and hydroalcoholic extract of cultivated thyme: antioxidant and antibacterial activities, and phenolic characterisation. Food Chem. 167, 131-137. http://dx.doi.org/10.1016/j.foodchem.2014.06.094.

Martins, N., Ferreira, I.C.F.R., Barros, L., Carvalho, A.M., Henriques, M., Silva, S., 2015b. Plants used in folk medicine: the potential of their hydromethanolic extracts against Candida species. Ind. Crops Prod. 66, 62-67. http://dx.doi.org/10.1016/j.indcrop 2014.12.033.

Martins, N., Barros, L., Santos-Buelga, C., Ferreira, I.C.F.R., 2016. Antioxidant potential of two Apiaceae plant extracts: a comparative study focused on the phenolic composition. Ind. Crops Prod. 79, 188-194. http://dx.doi.org/10.1016/j.indcrop.2015.11. 018.

Meléndez, P.A., Capriles, V.A., 2006. Antibacterial properties of tropical plants from Puerto Rico. Phytomedicine 13, 272-276. http://dx.doi.org/10.1016/j.phymed. 2004.11.009.

Mordmuang, A., Shankar, S., Chethanond, U., Voravuthikunchai, S.P., 2015. Effects of Rhodomyrtus tomentosa leaf extract on Staphylococcal adhesion and invasion in bovine udder epidermal tissue model. Nutrients 7, 8503-8517.

Motlagh, M.K., Yahyaei, M., Rezaei, M., Ghorbanpour, M., 2013. Study on Antibacterial Effect of Thyme and Peppermint Aqueous Extracts on Staphylococcus Aureus and Escherichia Coli Strains Causing Mastitis in Camels. pp. 112-115 Researchgate.net 1.

Mubarack, H.M., Doss, A., Dhanabalan, R., Venkataswamy, R., 2011. Activity of some selected medicinal plant extracts against bovine mastitis pathogens. J. Anim. Vet. Adv. 10, 738-741. http://dx.doi.org/10.3923/javaa.2011.738.741.

Pieterse, R., Todorov, S., 2010. Bacteriocins: exploring alternatives to antibiotics in mastitis treatment. Brazilian J. Microbiol. 41, 542-562.

Pires, C., Martins, N., Carvalho, A.M., Barros, L., Ferreira, I.C.F.R., 2016. Phytopharmacological preparations as predictors of plants bioactivity: a particular approach to Echinacea purpurea (L.) Moench antioxidant properties. Nutrition 1-6. http://dx.doi.org/10.1016/j.nut.2016.01.005.

Roriz, C.L., Barros, L., Carvalho, A.M., Santos-Buelga, C., Ferreira, I.C.F.R., 2014. Pterospartum tridentatum, Gomphrena globosa and Cymbopogon citratus: a phytochemical study focused on antioxidant compounds. Food Res. Int. 62, 684-693. http://dx.doi.org/10.1016/j.foodres.2014.04.036.

Rossi, C.C., Aguilar, A.P., Diaz, M.A.N., Ribon, A.O.B., 2011. Aquatic plants as potential sources of antimicrobial compounds active against bovine mastitis pathogens. AFRICAN J. Biotechnol. 10, 8023-8030. http://dx. doi.org/10.5897/AJB11.440.

Sabour, P.M., Gill, J.J., Lepp, D., Pacan, J.C., Ahmed, R., Dingwell, R., Leslie, K., 2004. Molecular typing and distribution of Staphylococcus aureus isolates in Eastern Canadian dairy herds. J. Clin. Microbiol. 42, 3449-3455. http://dx.doi.org/10.1128/ JCM.42.8.3449-3455.2004.

Santos, S.A.O., Freire, C.S.R., Domingues, M.R.M., Silvestre, A.J.D., Neto, C.P., 2011. Characterization of phenolic components in polar extracts of eucalyptus globulus labill. Bark by high-performance liquid chromatography-mass spectrometry. J. Agric. Food Chem. 59, 9386-9393. http://dx.doi.org/10.1021/jf201801q.

Santos, S.A.O., Villaverde, J.J., Freire, C.S.R., Domingues, R.M.M., Neto, C.P., Silvestre, A.J.D., 2012. Phenolic composition and antioxidant activity of Eucalyptus grandis, E. urograndis (E. grandis $\times$ E. urophylla) and E. maidenii bark extracts. Ind. Crops Prod. 39, 120-127. http://dx.doi.org/10.1016/j.indcrop.2012.02.003.

Santos, A., Barros, L., Calhelha, R.C., Dueñas, M., Carvalho, A.M., Santos-Buelga, C., Ferreira, I.C.F.R., 2013. Leaves and decoction of Juglans regia L.: different performances regarding bioactive compounds and in vitro antioxidant and antitumor ef fects. Ind. Crops Prod. 51, 430-436. http://dx.doi.org/10.1016/j.indcrop.2013.10. 003.

Saranraj, P., Sivasakthi, S., 2014. Medicinal plants and its antimicrobial properties: a review. Glob. J. Pharmacol. 8, 316-327. http://dx.doi.org/10.5829/idosi.gjp.2014.8. 3.83194 .

Sutra, L., Poutrel, B., 1994. Virulence factors involved in the pathogenesis of bovine intramammary infections due to Staphylococcus aureus. J. Med. Microbiol. http://dx. doi.org/10.1099/00222615-40-2-79.

Tanzi, C.D., Vian, M.A., Ginies, C., Elmaataoui, M., Chemat, F., 2012. Terpenes as green solvents for extraction of oil from microalgae. Molecules 17, 8196-8205. 